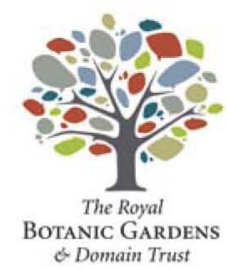

plantnet.rbgsyd.nsw.gov.au/Telopea • escholarship.usyd.edu.au/journals/index.php/TEL • ISSN 0312-9764 (Print) • ISSN 2200-4025 (Online)

\title{
NEOBY RNESIA (RUTACEAE): A NEW GENUS ENDEMIC TO NORTHERN AUSTRALIA
}

\author{
J. A. Armstrong and Jocelyn M. Powell
}

(Accepted 5.7.1978)

\begin{abstract}
Armstrong, J. A. and Jocelyn M. Powell (National Herbarium of New South Wales, Royal Botanic Gardens, Sydney, Australia 2000) 1980. Neobyrnesia (Rutaceae): A new genus endemic to Northern Australia. Telopea 1 (6): 399-403, Fig. 1, Pl. XV-XVII.-Neobyrnesia suberosa Armstrong, gen. et sp. nov. is described and discussed. Allied to genera in the sub-tribe Boroniinae sensu Engler (1931), Neobyrnesia is distinguished from other genera of Rutaceae in the AustralasianMalesian region by the following combination of characters: leaves simple and opposite; flowers 4-merous with persistent petals; stamens equal in number to the petals, antesepalous and persistent; intrastaminal disc continuous and unlobed; carpels each with two collateral ovules; and explosive capsular fruits. This monotypic genus is endemic to the East Alligator River area of the Northern Territory.
\end{abstract}

\section{Neobyrnesia Armstrong, gen. nov.*}

Fruticuli caulibus debilibus. Folia simplicia, opposita, integra. Inflorescentiae axillares. Petala 4, persistentia. Stamina 4, extra discum inserta, antesepala, persistentia. Discus integer. Carpella sublibera, medium versus faciei adaxialis stylo singulo juncta. Ovula collateralia. Stigma breviter quadrilobatum. Semina lineolata.

Small, weak-stemmed, shrubby plants, indumentum of simple hairs, velutinous. Leaves simple, opposite, decussate, petiolate, entire. Inflorescences axillary, fewflowered dichasial cymes. Flowers bisexual, protandrous, shortly pedicellate; sepals 4 , basally connate, persistent; petals 4 , free, valvate in bud, apically hooked, persistent; stamens 4, inserted outside the disc, antesepalous, persistent; filaments smooth, sublinear, tapering to a subulate apex; anthers 2-celled, introrse, dehiscing longitudinally, dorsifixed and versatile, thecae glabrous; disc hypogynous, entire, forming a narrow obscure margin around the ovary (Figure 1, A); gynoecium 4-carpellate; carpels free (slightly united at base), closely appressed; placentation axile; ovules 2 per locule, collateral; style solitary, inserted centrally in the shallow depression between the carpels; stigma 4-lobed. Fruit of 1-4 basally connate cocci (Plate XVII, 1) each dehiscing along the adaxial margin; undeveloped carpels, if any, persistent; pericarp at maturity consisting of a dry coriaceous epicarp $\dagger$ and a cartilaginous, elastic endocarp. Seeds, one per coccus, expelled explosively (Figure 1, D-F), lineolate; elaiosomeł fleshy on lower central part and membraneous on upper and lateral margins, firmly attached and persistent; the aborted ovule persistent beneath the elaiosome; testa two-layered, inner layer (sclerotesta) noticeably thicker, crustaceous, sculptured; hilum a shallow groove along adaxial margin extending from micropyle (near apex of seed below prominent beak) to raphe (Plate $\mathrm{XV}, 2-5)$; endosperm copious; embryo terete.

\footnotetext{
* The authority of both genus and species is to be cited as "Armstrong", not "Armstrong ex Armstrong \& Powell".

$\dagger$ Epicarp refers to the two outer layers of the pericarp.

$\ddagger$ The placental portion of the endocarp.
} 
Plate XV

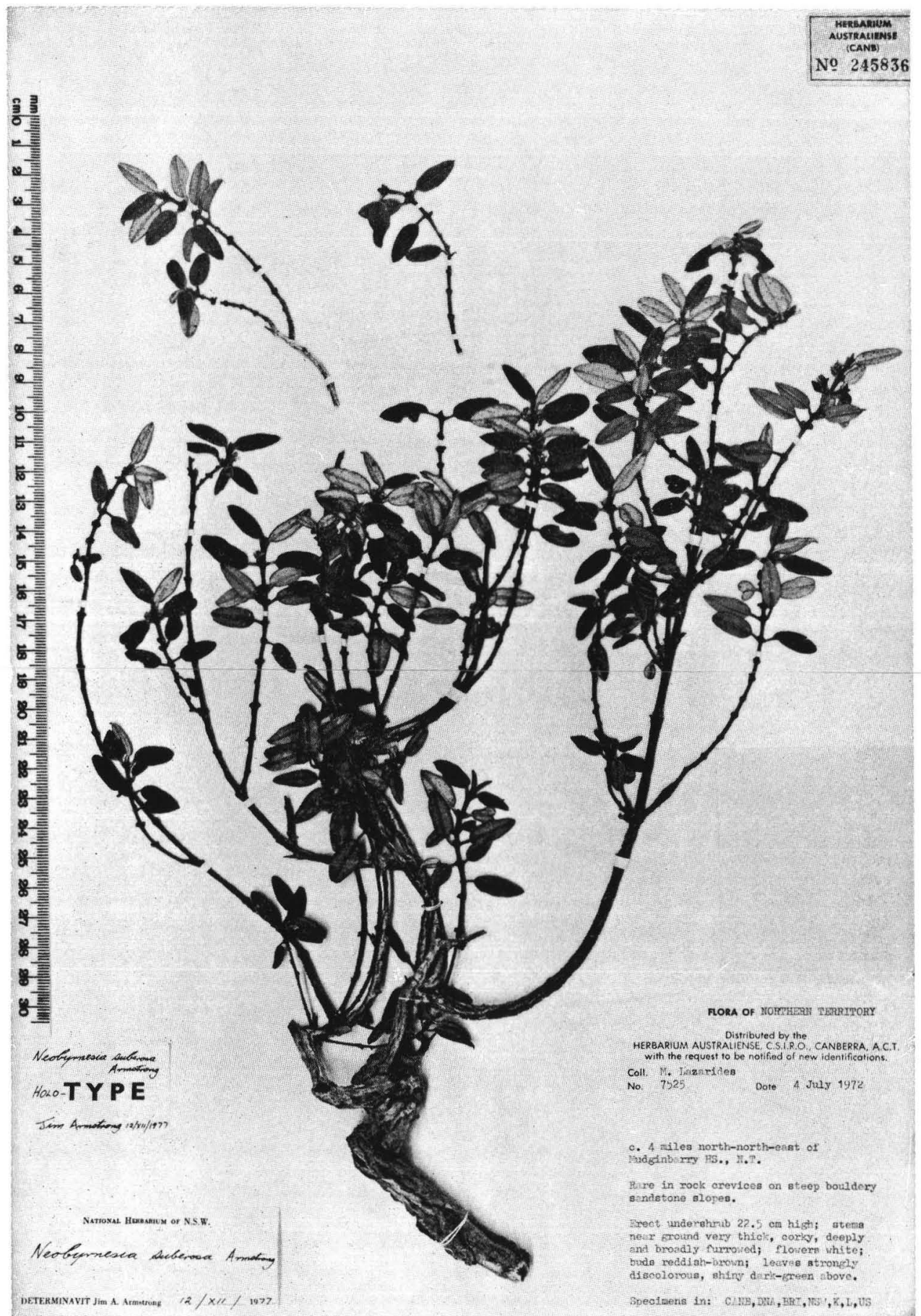


Holotype AND only Species: N. suberosa Armstrong, from northern Australia.

The genus is named in honour of Norman B. Byrnes* who, in 1968, first collected this taxon, and whose work in northern Australia has significantly advanced our botanical knowledge of that region.

\section{Neobyrnesia suberosa Armstrong, sp. nov.}

Holotype: Northern Territory: Darwin and Gulf District: c. 4 miles [6 km] NNE. of Mudginbarry Hs., rare in rock crevices on steep bouldery sandstone slopes, M. Lazarides 7525, vii.1972 (CANB 245836!). IsOTYPES: DNA, BRI, NSW!, K, L, US. Plate XV.

Fruticulus usque $30 \mathrm{~cm}$ altus. Cortex profunde sulcatus, colore cremeo, suberosus. Ramuli juniores et foliorum paginae inferiores indumento denso e pilis simplicibus sistente ornati. Folia oblongo-lanceolata usque ovata, $1.5-4.6 \mathrm{~cm}$ longa, 0.6-1.6 cm lata. Flores albi, inconspicui, ovario apice pubescenti, stylo glabro. Fructus subglabri.

Weak-stemmed shrub to $30 \mathrm{~cm}$ high. Branches either slender and upright or lax and pendulous; indumentum of simple hairs, velutinous, reddish brown on younger branches, white to creamy white on more mature branches; older branches glabrescent, with a deeply furrowed, cream-coloured, corky bark. Leaves simple, petiolate; petioles $2.4-6.1 \mathrm{~mm}$ long, velutinous; laminas oblong-lanceolate to ovate, $1.3-4.0 \mathrm{~cm}$ long, $0.6-1.6 \mathrm{~cm}$ wide, mucronate at the apex, strongly discolourous, dark green above, white to cream below; margin entire, occasionally slightly recurved; upper surface alveolate at high magnification (Plate XVI, 1), glabrous except for a line of pubescence along the mid-vein depression (Plate XVI, 2), conspicuously oil-dotted; undersurface velutinous with creamy white and reddish brown hairs (Plate XVI, 3); primary vein on undersurface prominent, venation otherwise obscure. Inflorescence shorter than leaves, 3-7-flowered; peduncle $0.8-1.5 \mathrm{~mm}$ long, pubescent; bracts inconspicuous, pubescent; pedicels elongating at the fruiting stage to $2.8 \mathrm{~mm}$ long, pubescent. Flowers white, inconspicuous, $2.5 \mathrm{~mm}$ across; calyx lobes ovate, $1.3-1.7 \mathrm{~mm}$ long, $1.0-1.2 \mathrm{~mm}$ wide, much shorter than the petals, tomentose abaxially with cream-coloured hairs interspersed with reddish brown hairs, glabrous adaxially; petals persistent, ovate, $2.0 \mathrm{~mm}$ long, 1.1-1.5 mm wide, outer surface pubescent, inner surface glabrous (Plate XVI, 4) stamens persistent; filaments $1.3 \mathrm{~mm}$ long, glabrous, dilated towards base, tapering towards apex; anthers $0.7 \mathrm{~mm}$ long, $0.6 \mathrm{~mm}$ wide, unappendaged, attached about the middle. Pollen monad, tricolporate, prolate (Plate XVI, 5), 18-22 $\mu \mathrm{m}$ long, 16-19 $\mu \mathrm{m}$ wide, reticulate; sexine same thickness as nexine; reticulum clear, lumen varying in size up to $1 \mu \mathrm{m}$ diameter (Plate XVI, 6); colpus broad, with indistinct margins; transverse colpus c. $6 \mu \mathrm{m}$ long, $2 \mu \mathrm{m}$ wide, with rough, somewhat thickened margins (Plate XVI, 7). Disc encircling ovary, $0.15 \mathrm{~mm}$ high. Ovary pubescent at apex and along adaxial margin, elsewhere glabrous; style $0.5-0.9 \mathrm{~mm}$ long, glabrous; stigma c. $0.2 \mathrm{~mm}$ across. Fruit reddish brown, glabrous except for a few scattered hairs on the outer surface of each coccus and a line of pubescence at apex and along adaxial margin (Plate XVII, 1). Seed solitary in each coccus, dark reddish brown, $3.0-4.0 \mathrm{~mm}$ long, $1.5-2.0 \mathrm{~mm}$ broad; surface lineolate, at high magnification (Plate XVII, 3, 5) seen as parallel ridges about 36-40 $\mu \mathrm{m}$ apart, with individual units each composed of 2 sloping rectangular cells (20-22 $\mu \mathrm{m}$ long, 13-16 $\mu \mathrm{m}$ wide) plus a central apical oval to rounded cell (9-13 $\mu \mathrm{m}$ across), flakes of wax obvious (Plate XVII, 5); elaiosome present on the adaxial margin, $2.5 \mathrm{~mm}$ long, $1.4 \mathrm{~mm}$ wide (Plate XVII, 2-4).

\footnotetext{
* Formerly Botanist, Primary Industries Branch, Northern Territory Acministration, Darw'n, from 1967-73 and subsequently at the Queensland Herbarium, Brisbane.
} 

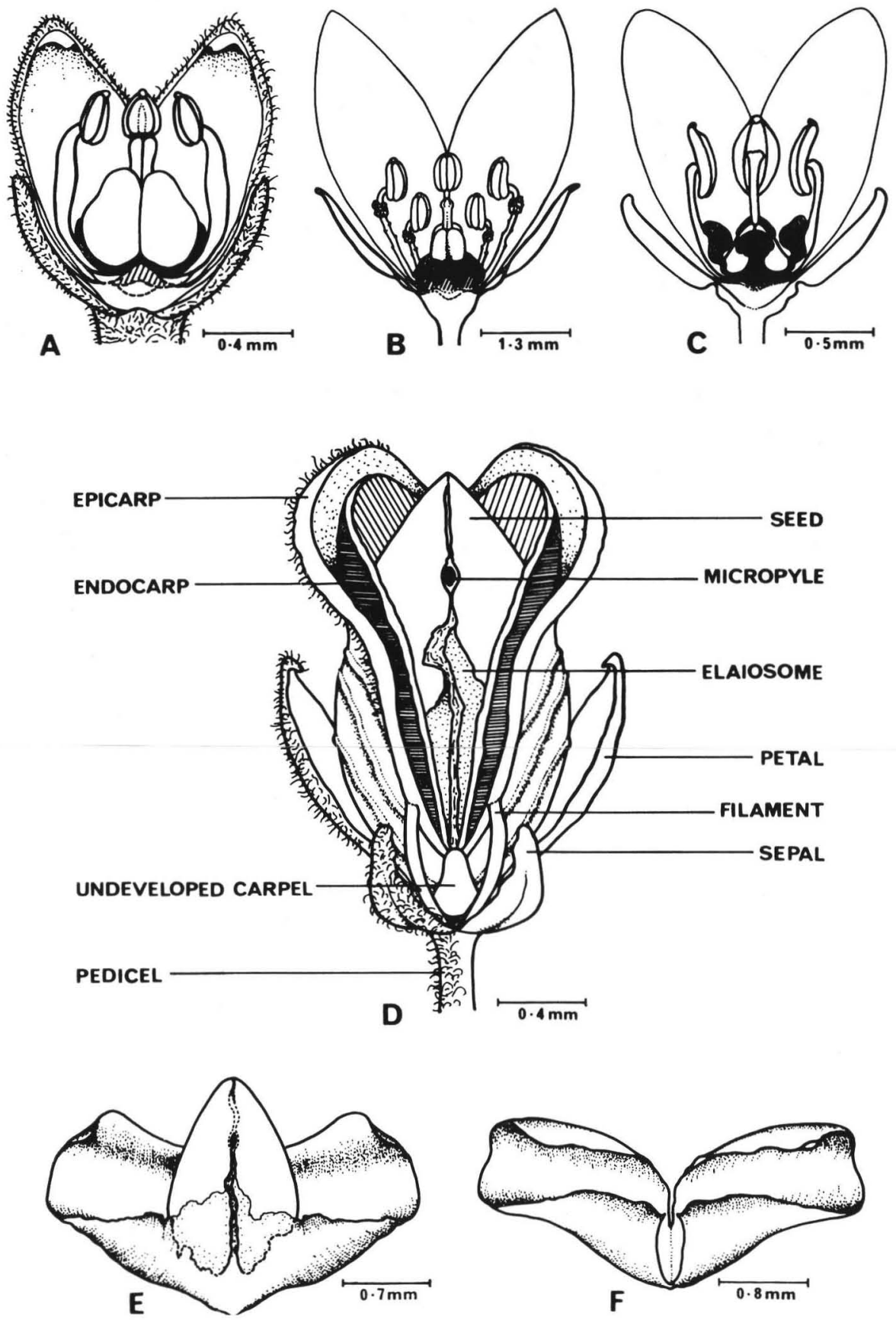

Figure 1. A-C: Longitudinal section of flowers (with a sepal, 2 petals, 1 stamen ( 3 in Boronia) removed) of (A) Neobyrnesia, (B) Boronia and (C) Zieria, showing position and shape of disc (in black); D-F: fruit and seed of Neobyrnesia suberosa.-A. Neobyrnesia suberosa: disc inconspicuous, entire. B. Boronia deanei: disc conspicuous, entire, and cushion-shaped. C. Zieria robusta: disc conspicuous with 4 distinct antesepalous lobes. D. Fruit, with persistent petals and filaments attached, showing a mature single coccus and seed. E. Seed with twisting endocarp prior to expulsion. F. Twisted endocarp separated from seed following expulsion from coccus. 
Derivation of Name: The specific epithet 'suberosa' (Latin: suberosus $=$ corky) refers to the deeply furrowed cream coloured corky bark, characteristic of the older branches of this species.

Distribution: Endemic to the East Alligator River area of the Northern Territory, c. $12^{\circ} 30^{\prime}$ S., $133^{\circ}$ E. (Map 1)

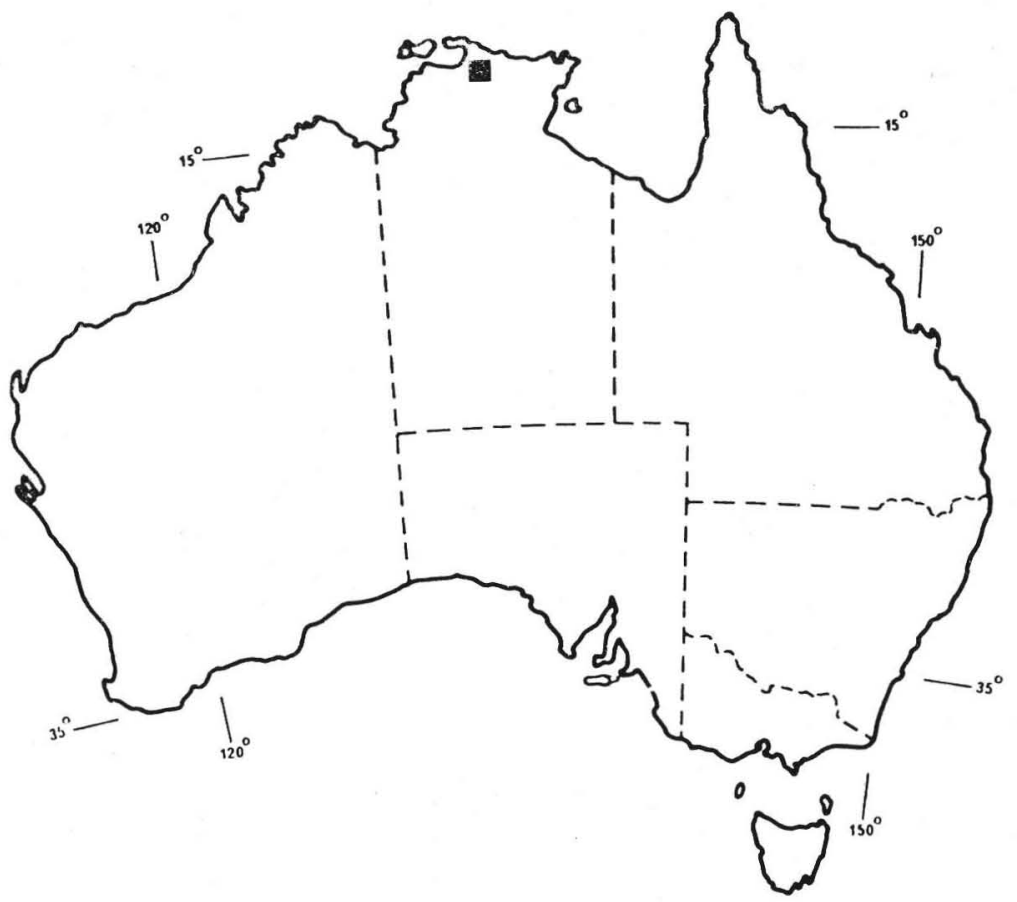

Map 1. Distribution of Neobyrnesia suberosa Armstrong

ECOLOGY: Restricted to shallow skeletal soils on sandstone cliff-faces in rocky crevices and horizontal fractures. Collections have been made in February, May, June and July; all these specimens have flowers and fruits present.

Biology: Although living material has not been studied, the protracted flowering and fruiting period, coupled with the inconspicuous nature of the flowers (which, in other members of the tribe Boronieae, is indicative of autogamy) suggest that self-pollination occurs in this species. Neobyrnesia suberosa has protandrous flowers; at first the style is short, but it lengthens during anthesis, while the stigma reaches maturity towards the end of anther dehiscence.

Specimens Examined: Northern Territory: Darwin \& Gulf District: East Alligator River, 1 mile [1.5 km] E. of Crossing, Byrnes 826, 5.1968 (NT 14485-pollen voucher J.M.P. 1096; fl., fr.), Byrnes 2720, 7.1972 (NT 32671—seed morphology voucher J.M.P. 623, CANB 233197: fl., fr.); East Alligator River, c. $2 \mathrm{~km}$ S. of Crossing, $12^{\circ} 26^{\prime}$ S., $132^{\circ} 57^{\prime}$ E., Jacobs $1825,6.1974$ (NSW; fl., fr.); c. 4 miles [6.5 km] NNE. of Mudginbarry Hs., Lazarides 7525, 7.1972 (CANB 245836-HOLOTYPE, NSW-ISOTYPE and pollen voucher J.M.P. 1752; fl. fr.); ESE. of Mudginbarry 'Mudginberry', $12^{\circ} 36^{\prime} \mathrm{S}, 132^{\circ} 58^{\prime}$ E, Dunlop 3292, 2.1973 (NSW, CANB 246826, BRI. 168422 - seed morphology voucher J.M.P. 624 and pollen voucher J.M.P. 1097; fl., fr.); Tributary

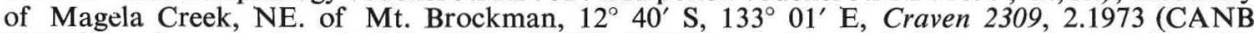
245838 - pollen voucher J.M.P. 1753, CANB 245830 - seed morphology voucher J.M.P. 625, NSW; fl., fr.). 


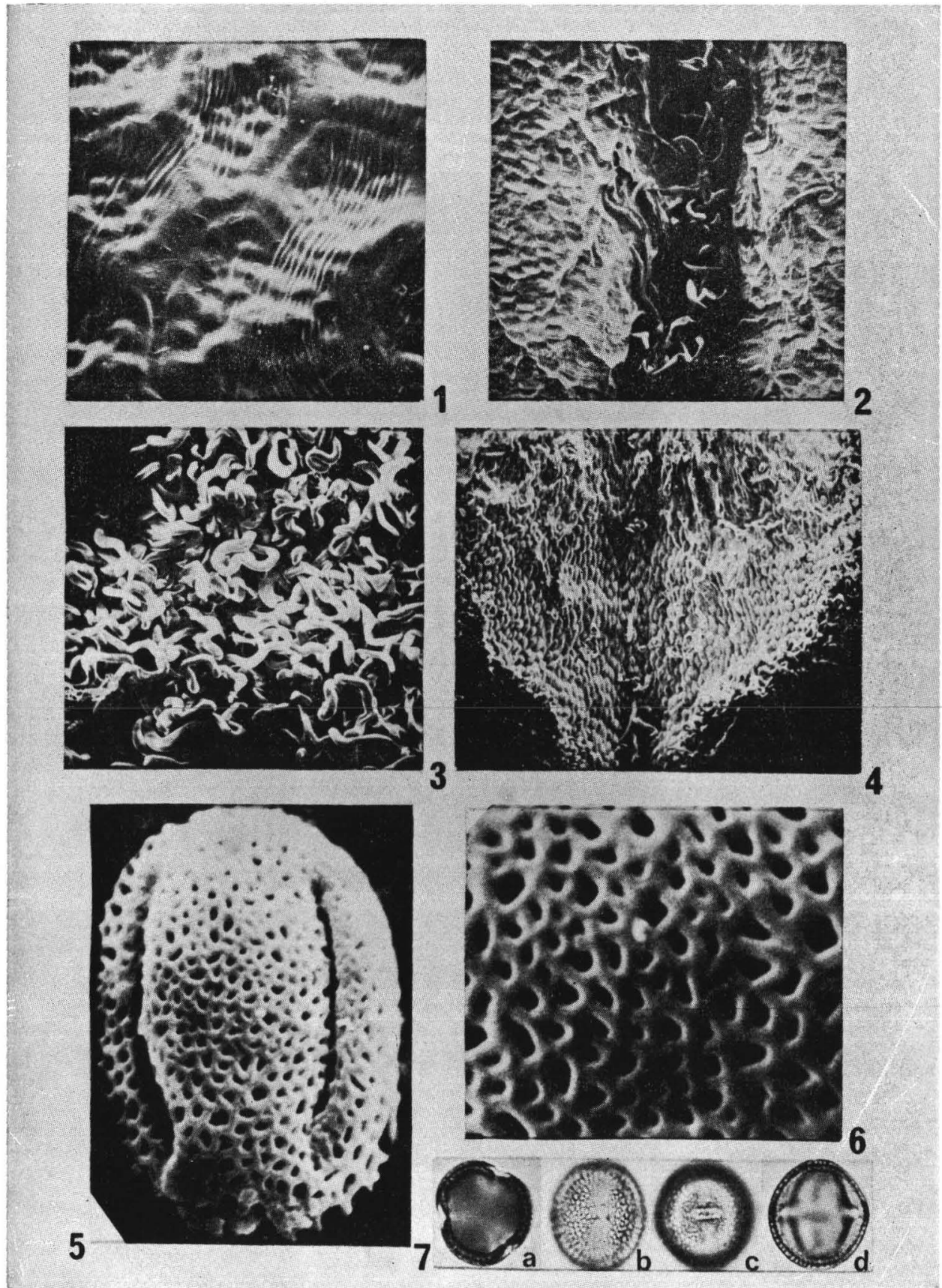

Neobyrnesia suberosa: Scanning electron micrographs of leaf, petal and pollen grain surfaces; light micrographs of pollen.-1. Upper surface of lamina, glabrous, alveolate, $\times 675$. 2. Upper leaf surface, pubescence in mid-vein depression, $\times$ c. 68 . 3. Indumentum on leaf undersurface, $\times$ 135. 4. Adaxial surface of petal, $\times$ c. 68. 5. Pollen grain, prolate, $\times 2700$. 6. Pollen grain reticulum, $\times 5400$. 7. Pollen grain structure: (a) polar view, (b) reticulum plus colpus, (c) transverse colpus, (d) equatorial view, all $\times 750$ magn. 


\section{GENERIC RELATIONSHIPS}

Within the existing hierarchy of the family Rutaceae (Engler 1896, 1931; Melchior 1964), Neobyrnesia is placed in the tribe Boronieae and its closest affinity is with genera in the sub-tribe Boroniinae (Table 1). This newly described genus has a number of distinctive characters and others which indicate relationship with either Boronia or Zieria (Table 2).

TABLE 1

CHARACTERISTICS OF GENERA CURRENTLY INCLUDED IN THE SUB-TRIBE BORONIINAE

\begin{tabular}{l|c|c|c|c|c|c}
\hline \multicolumn{1}{c|}{ Genus } & $\begin{array}{c}\text { No. } \\
\text { Species }\end{array}$ & $\begin{array}{c}\text { No. } \\
\text { Carpels }\end{array}$ & $\begin{array}{c}\text { Ratio of } \\
\text { Petal to } \\
\text { Stamen } \\
\text { Number }\end{array}$ & $\begin{array}{c}\text { No. } \\
\text { Ovules } \\
\text { per Carpel }\end{array}$ & $\begin{array}{c}\text { Dehiscent } \\
\text { Fruit }\end{array}$ & Distribution \\
\hline 1. Acradenia & 2 & $5(6)$ & $1: 2$ & 2 & + & A \\
2. Myrtopsis & 7 & 5 & $1: 2$ & 1 & + & NC \\
3. Boronella & 3 & 4 & $1: 2$ & 1 & + & NC \\
4. Boronia & 95 & 4 & $1: 2$ & 2 & + & A, NC? \\
5. Neobyrnesia & 1 & 4 & $1: 1$ & 2 & + & A \\
6. Zieria & c. 25 & 4 & $1: 1$ & 2 & + & NC NC \\
7. Zieridium & c. 3 & 4 & $1: 1$ & 1 & - & NC \\
\hline
\end{tabular}

$+=$ present, $-=$ absent, $\mathrm{A}=$ Australia, $\mathrm{NC}=$ New Caledonia.

The disc in Neobyrnesia is entire, forming a narrow ring around the ovary. Both Boronia and Zieria have a more conspicuous disc; in most species of Boronia it is entire and cushion-shaped*, while in Zieria it has 4 distinct antesepalous lobes (Figure 1, A-C).

Stamens and petals are equal in number for Neobyrnesia and Zieria; in Neobyrnesia these organs persist at the fruiting stage, whereas they are deciduous in Zieria. Boronia has twice as many stamens as petals; these organs are usually deciduous, but in some species, for example, those of the "Valvatae" of Bentham (1863, p. 308), they are retained at the fruiting stage.

All three genera have tricolporate and reticulate pollen. In size and shape of the pollen grain and in size of the reticulum lumen, Neobyrnesia is close to Zieria but in wall structure and transverse colpus structure the new genus resembles some species of Boronia.

The ovules in Neobyrnesia are collateral, whereas in both Zieria and Boronia they are superimposed. Although Bentham (1863, p. 314) states in his description of Boronia ledifolia that the ovules are "usually, as in some allied species, almost or quite collateral", examination of numerous $B$. ledifolia carpels showed that the ovules are superimposed. P. G. Wilson (pers. comm.) suggests that the ovules of all Australian members of the tribe Boronieae, arrive collaterally but in some they become displaced during development - apparently, the final position of the ovules in each carpel is dependent on space.

\footnotetext{
* Exceptions are the antesepalously lobed discs of Boronia tetrandra and $B$. purdieana and the antepetalously lobed disc of B. octandra (Wilson 1971, p. 200).
} 
Plate XVII

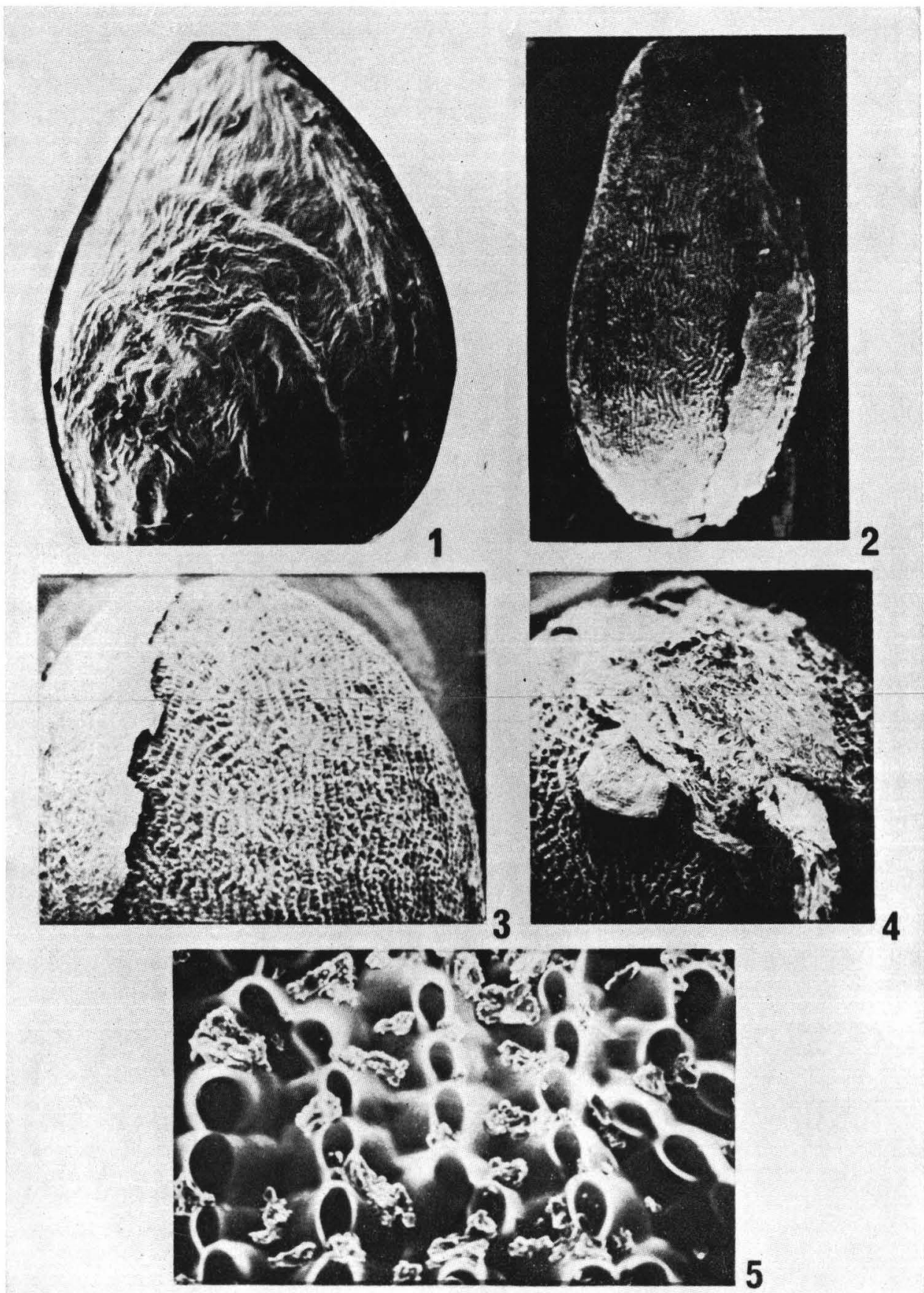

Scanning electron micrographs of fruit and seed surface structure of Neobyrnesia suberosa.1. Fruit: outer surface of a single coccus, $\times$ c. 23 . 2. Seeds with prominent beak obvious (top right), elaiosome attached (lower right), $\times$ c. 23 . 3. Seed surface, $\times 45$. 4. Elaiosome with aborted ovule, $\times 45$. 5. Seed surface lineolate, wax flakes obvious, $\times 450$ magn. 
Finally, Neobyrnesia differs from the other genera in having a distinctive seed coat pattern. Some Boronias have completely smooth seeds while others have tuberculate, reticulate or verrucate surface patterns. Most Zierias have ridged seeds ( $Z$. pilosa is tuberculate) and in this respect resemble those of Neobyrnesia. Although the elements of the surface structure are similar in both genera, the overall pattern formed in Zieria is never the same as that found in the new genus.

TABLE 2

COMPARISON OF AT'TRIBUTES PRESENT IN THE GENERA NEOBYRNESIA, BORONIA A.ND ZIERIA.

\begin{tabular}{|c|c|c|c|c|}
\hline \multicolumn{2}{|r|}{ Attribute } & Neobyrnesia & Boronia & Zieria \\
\hline Leaves: & opposite & + & & $+(-)$ \\
\hline Petals: & $\begin{array}{l}\text { simple } \\
\text { persistent in fruit }\end{array}$ & + & $\begin{array}{l}-(+) \\
-(+)\end{array}$ & $-(+)$ \\
\hline Stamens: & equal in number to the petals & + & & + \\
\hline & persistent in fruit & + & $-(+)$ & - \\
\hline Pollen: & prolate in shape & + & $-(+)$ & + \\
\hline & $\begin{array}{l}\text { dimensions of grain } \leq 25 \mu \mathrm{m} \\
\text { reticulum lacking distinct baculae }\end{array}$ & + & $\overline{+}(-)$ & $\pm(-)$ \\
\hline & lumen of reticulum $\leq 1 \mu \mathrm{m}$ & + & & + \\
\hline & two walls of same thickness & + & $+(-)$ & - \\
\hline Disc: & $\begin{array}{l}\text { transverse colpus thickened } \\
\text { with } 4 \text { distinct antesepalous lobes }\end{array}$ & \pm & $\begin{array}{l} \pm(-) \\
-(+)\end{array}$ & \\
\hline Ovules: & collateral & + & & $+(-)$ \\
\hline Seeds: & ridged & + & - & $+(-)$ \\
\hline & $\begin{array}{l}\text { apical cell of unit oval to round } \\
\text { cells between ridges parallel }\end{array}$ & + & $\begin{array}{l}- \\
-\end{array}$ & $-(+)$ \\
\hline & cells rectangular in shape & + & - & $+(-)$ \\
\hline
\end{tabular}

$+=$ present, $-=$ absent, $($ ) indicate the rare alternative condition.

The tribal classification of the Rutaceae as proposed by Engler $(1896,1931)$ is partly incompatible with currently available data (Hartley 1974, 1977, Armstrong 1975 a $\&$ b). Of the 5 sub-tribes of the Boronieae distinguished by Engler (1931), the generic composition of the Boroniinae (Table 1) requires reappraisal. Hartley (1977) suggested that Acradenia is misplaced, probably being more closely related to genera in the tribe Zanthoxyleae. The genus Zieridium (with 1 ovule per carpel and indehiscent fruits) is possibly also incorrectly placed in the sub-tribe. The remaining endemic New Caledonian genera Myrtopsis and Boronella (each with 1 ovule per carpel but with dehiscent fruits) are also doubtfully placed in the Boroniinae.

Although the present circumscription of the Boroniinae will undoubtedly change (as part of a general reappraisal of the tribe Boronieae, J. Armstrong, unpublished data), the three genera Boronia, Neobyrnesia and Zieria will remain a coherent group within the sub-tribe.

\section{ACKNOWLEDGEMENTS}

The authors wish to thank Dr M. D. Tindale for assistance with the Latin descriptions, Ms C. Payne for the diagrams, Mr P. Finlay for the photographic reproductions and Mr D. McGillivray for his helpful discussion of the manuscript. We are grateful also to the Directors of the following herbaria for making loans of this new taxon available for study: Queensland Herbarium (BRI), Herbarium Australiense (CANB) and the Herbarium of the Northern Territory Administration (NT). 


\section{LITERATURE CITED}

Armstrong, J., 1975a-The family Rutaceae. Austral. Pl. 8: 195-199, 212-214.

Armstrong, J., 1975b--The family Rutaceae in Australia. Austral. Pl. 8: 215-225.

Bentham, G., 1863-Flora Australiensis. 1: 301-372. Lovell Reeve \& Co., London.

Engler, A., 1896-Rutaceae. In A. Engler \& K. Prantl, Nat. Pflanzenfam. 3 (4): 95-201. Duncker \& Humboldt, Berlin.

Engler, A., 1931-Rutaceae. Ibid. ed. 2, 19a: 187-358.

Hartley, T. G., 1974-A revision of the genus Acronychia (Rutaceae). J. Arnold Arbor. 55: 469-523, 525-567.

Hartley, T. G., 1977-A revision of the genus Acradenia (Rutaceae). J. Arnold Arbor., 58: 171-181.

Melchior, H. [ed.], 1964-Rutaceae. In A. Engler's Syllabus Der Pflanzenfamilien. ed. 12, 2: 263-266. Gebrüdwe Borntraeger, Berlin.

Wilson, P. G., 1970-A taxonomic revision of the genera Crowea, Eriostemon and Phebalium (Rutaceae). Nuytsia 1 (1): 1-155.

Wilson, P. G., 1971-Taxonomic notes on the family Rutaceae, principally of Western Australia. Nuytsia 1 (2): 197-207. 